トズーミング法の臨床における有用な使用法について検討したの で報告する。

〔万法〕 FOV 制限 $15 \mathrm{~cm}$ と FOr 制限 $10 \mathrm{~cm}$ の SE 法シーケン スに扔いて, SNR と空間分解能を求め, 正常ボランティアにて比較 し，高速 SE法, MRAについても険討した。

〔結果〕ダイレクトズーミング法は制限より $5 \mathrm{~cm}$ 小さな FOV を使用する場合に有用であり，ファインリコンストラクション法を 併用子ることにより空間分解能も改善され，制限上り $5 \mathrm{~cm}$ 小さい FOVを使用してもSNRの低下汢みら机なかった。高速 SE 法, MRA 等, FOV 制限の強い撮像法の場合に有用であった.ファイン リコンストラクション法を併用するこ上により四肢にも有用であ った.

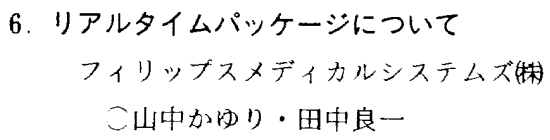

〔目的〕撮像に数分を要する従来のMRには患者の僅かな動き すら検査の妨げになっていました、リアルタイムバッケージはこの 問題の克服を目的としました。

〔方法〕 GIROSCANメTシリーズはTSE, TFE, GraSE, EPI と,超高速撮像法の全てをラインアップし，10枚/秒のリアルタイム イメージングを実現しました。がントリ一上部に設置したLCDモ ニタでMR 透視画像を見ながら患者にアプローチすることもでき ます。

〔結果〕超高速撮像はリアルタイムスキャンを可能とし，患者位 置決めスキャン, 動態観祭, さらには術中でのスキャンと新たな臨 床応用の可能性を広げます。

\section{SSFP を利用した脊㩆空洞症の評価}

\section{埼玉医科大学}

气石北正則・津田和幸・采沢大志・山䗁富雄・宮前悦子 定常歳差状態 (SSFP) を用いた高速撮像法の一つである PSIF 法 は，T2強調型の画像コントラストを短時間で得られるため脳春哊 液の画像化に役立っているが，今回この撮像法と SE 法による T2 強調画像との比較評洒を行ったので報告する.

PSIF，FISP 法のパルス系列では，磁場勾配の印可方向による信 号強度の違いが明確に表れた。またPSIF 法では，流速を持つ成分 においてSSFPが成立しにくいことを反映しているため他のバル ス系列に比べて流速を変えたときの信号変化が顥著に見られた。し たがって SE 法よも流れに鋭敏であり，脊髄空洞内の拍動の有無が 分かるものと考える。

8. 心筋ダイナミック MRIの一技法

埼玉県立小原循環器病センター

二山内辰磪・松田一秀・川島健司・村田孝弘・矢部 仁 福田 公・横山 俊

〔目的〕高速撮影法を用いたダイナミック MRIによる心筋血㐬 動態解析が報告されているが, その画質については十分な謤価がな されるに至っていない. 今回，ダイナミックイメージの画質上名パ ラメーターの関係を検討し，シーケンスの最適化を計るとともに， 臨床例により，その有用性を認めたので報告する。

【結果〕各パラメーターの内, プリパルスディレイタイムが, SN 比，コントラストに影謷し， $300 \mathrm{~ms}$ 以下では，心筋の信号法弱い。 また, TFEショット数が多い場合, モーションアーチファクトの原 因となるため，2 または 3 が適当である。臨床例の検討では，1撮
像10秒のスキャンでも，虚血部の定性的評価は可能である。

9. MRI 脊椎検查時における Turbo Spin Echoを用いた高分解 能撮影の有用性について

埼玉県立小原循環器病センター

$$
\text { 二松田一秀・山内辰雄・矢部 仁・村田孝弘・川島健司 }
$$$$
\text { 大澤 伸・福田 公・横山 俊 }
$$

〔目的〕当センターでは平成 6 年 4 月の開院時より, 高速撮像可 能なMRI 装置が導入され, 稼動を開始した。今回, 高速撮影法の 中でも特に, Turbo Spin Echo 法を春椎の高行解能撮影に応用し， 矢状面の $\mathrm{T}_{2}$ 強調画像に㧈ける各種アーチファクトなどの影響を 減少させるための撮影法について検討したので報告する。

〔結果〕高速高分解能撮影により得られた画像は各種アーチフ アクトの影響も少なく，解剖学的位置関係が，正しく鲜明に画像が 描出された。また，撮像時間の短縮化が計られた。

\section{0，顎関節 MRIにおける撮像角度の検討}

横浜労災病院

$$
\text { 一村文治・笠原英生・米島英明・佐藤律夫 }
$$

（目的）賈関節 MRIでの，関節円板の内外側方転位の骖断，お

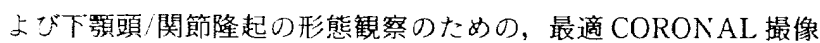
角度を検討した。

〔方法〕当院症例2000関節加，関節円板の位置，形態，下䫑頭 の変形に注目して病態分類し，また新鮮屋顥関節を用いて撮像角度 之誩断情報の違い在换討した。

〔結果〕 適応症例の多くに関節円板の転位, 変形がみられ，特に 前方転位が多いのが確認できた。最適撮像角度は,下預頭/関節結節 を結ぶ面に対して，垂直ニうで関節円板の識別能が向上した。

〔まとめ〕 CORONAL 撮像角度の最適化によって，関節鏡視で は難しい外側転位等の診断能が向上した。

\section{座長集約}

本セクションは, 最新装置の紹介が 1 題, 撮影方法の検討に関す るもの4題の発表であった。

【演題 6】GYROSOAN NTシリーズのハード・ソフトの開発 を報告した，質問 (座長) ウルトラ TSEのTurbo Factor は最大 でどのくらい可能か.答 理論上は128まで可能である.質問 笠原 (横浜労災病院)エコー感覚は, 何 $\mathrm{ms}$ のオーダで可能か. スティミ ュレイテッドエコーは問題ないか. 荅 今のところ $6 \sim 8 \mathrm{~ms}$ 程度 である、ソフトのことは解りかねる。

【演題 】 SSFP法は, 流速の変化に対する感度が高く, 脊能空 洞症の診断に簡便で有用であると報告した，質問（座長）なぜ流速 を増やしてもFLASH 法で信号強度は変化しないか. 答 流速 0 の時点で信号強度が低すぎた，質問 (座長) TR17では，なぜ流速 $0.1 \mathrm{~mm} / \mathrm{sec} の$ 信号强度は上昇したのか. 答 測定誤差が考えられ る.

【演題 8】 心筋ダイナミックイメージの画質と, 各パラメータの 検討報告した。

【演題 9】顠椎の TSE 法を用いた高分解能撮影の検討報告した。 質問 栗田 (齐生会栗橋病院) SE 法と TSE 法の画像で, 推間板の 信号強度の違いは, 臨床上問題になったことはないか. 答 臨床上 の此較検討は行なっていない，また，当院では，全てTSE 法を使 用しているので問題になっていない。

【演題10】額関節の CORONAL 撮影角度の最適化により，診断 能が向上したとの報告であった。 